\title{
STUDI IN VIVO EFEKTIVITAS GEL EKSTRAK ETANOL DAUN BINAHONG (Anredera cordifolia (Tenore) Steen) SEBAGAI PENYEMBUH LUKA DIABETES
}

\author{
Kintoko*, Novitasari, P.R. \\ Fakultas Farmasi Universitas Ahmad Dahlan, Jl. Prof. Dr. Soepomo, Janturan, \\ Yogyakarta 55164, *maskinjogja@yahoo.com.sg/0822 20709977
}

\begin{abstract}
Diabetes mellitus (DM) is a disease characterized by increasing of blood sugar levels. High blood sugar levels could grow the bacteria causing various complications, such as diabetic ulcers. The gel of ethanolic extract of binahong (Anredera cordifolia (Tenore) Steen) leaves containing saponins, alkaloids, tannins, steroids, triterpenoids, flavonoids and ascorbic acid coud be as wound healer by antibacterial mechanism. The aim of this study was to determine the concentration of ethanolic extract gel of binahong leaves on diabetic wound healing process and knew the model of neutrofil polymorphonuclear inflamatory cells and its re-epithelialization process, then it has been seen through histopathologic preparat microscopically. This study used 25 Wistar white male rats that divided into 5 groups, there were negative control, positive control, normal control, and the treatment of ethanolic extract gel of binahong leaves; $10 \%$ and $30 \%$ concentrations. Then the skin histopathology in alloxan-induced rats was observed after treated by ethanolic extract gel of binahong leaves on $16^{\text {th }}$ and $23^{\text {th }}$ day. The skin histopathology showed, neutrofil polymorphonuclear inflamatory cells and re-epithelialization formed was reduced after treating by gel of ethanolic extract of $30 \%$ binahong leaves. In conclusion, the gel ethanolic extract binahong leaves could give the significant effects on diabetic wound healing.
\end{abstract}

Keywords: binahong leaves, ethanolic extract, wound healer, diabetic wounds

\begin{abstract}
ABSTRAK
Diabetes Melitus (DM) merupakan penyakit yang ditandai dengan meningkatnya kadar gula darah yang dapat menyebabkan berkembangnya bakteri dan menimbulkan berbagai komplikasi, seperti ulkus diabetik. Gel ekstrak etanol daun binahong (Anredera cordifolia (Tenore) Steen) yang mengandung saponin, alkaloid, tanin, steroid, triterpenoid, flavonoid dan asam askorbat dapat sebagai penyembuh luka melalui mekanisme antibakteri. Tujuan dari penelitian ini adalah mengetahui konsentrasi ekstrak etanol daun binahong pada proses penyembuhan luka diabetik serta mengetahui gambaran sel radang polimorfonuklear netrofil dan reepitelisasinya secara histologi. Penelitian ini menggunakan tikus jantan putih galur Wistar berjumlah 25 ekor yang dibagi dalam 5 kelompok, yaitu kontrol negatif, kontrol positif, kontrol normal, perlakuan gel ekstrak etanol daun binahong; konsentrasi $10 \%$ dan $30 \%$, kemudian dilakukan pengamatan terhadap gambaran histopatologi kulit tikus yang sebelumnya telah diinduksi aloksan agar mengalami diabetes dan diamati pada hari ke-16 dan hari ke-23. Hasil pengamatan histopatologi kulit tikus diperoleh data berkurangnya sel radang polimirfonuklear netrofil dan terbentuknya reepitelisasi setelah diberi gel pada konsentrasi 30\%. Dari hasil penelitian, disimpulkan bahwa pemberian gel ekstrak etanol daun binahong berefek signifikan pada penyembuhan luka diabetik.
\end{abstract}


Kata kunci : daun binahong,ekstrak etanol, penyembuh luka, luka diabetik

\section{PENDAHULUAN}

Diabetes Melitus (DM) merupakan penyakit yang ditandai dengan meningkatnya kadar gula dalam darah karena gangguan sistem metabolisme dalam tubuh, serta organ pankreas tidak mampu memproduksi hormon insulin sesuai kebutuhan tubuh (Junaidi, 2009). Pada tahun 1995, prevalensi penderita DM tercatat sebanyak 135 juta dan meningkat menjadi 217 juta pada tahun 2005 (Smyth et al., 2006). Prevalensi penderita DM mengalami peningkatan terutama di negara berkembang seperti Indonesia. WHO memprediksikan Indonesia akan mengalami kenaikan jumlah penderita dari 8,4 juta pada tahun 2000 menjadi 21,3 juta pada tahun 2030.

Komplikasi dalam penyakit DM membutuhkan waktu penyembuhan yang lama. $\mathrm{Hal}$ ini dikarenakan luka diabetik memiliki respon inflamasi yang memanjang (Margolis et al., 2013). Menurut Suriadi dalam Purbianto (2007), penyebab dari luka diabetik salah satunya adalah infeksi. Infeksi terdiri dari bermacam-macam bakteri. Bakteri yang lazim menginfeksi luka diabetik umumnya Staphylococcus aureus (gram positif) dan Streptococcus pyogenes (gram positif). Saat ini banyak penelitian yang dilakukan terhadap tanaman obat terkait manfaat antibakteri yang diberikan terhadap penyembuhan luka. Salah satu tanaman obat Indonesia yang sangat populer adalah tanaman binahong yang dipercaya sangat berkhasiat dalam proses penyembuhan luka. Bagian dari tanaman binahong yang memiliki banyak khasiat adalah pada bagian daunnya.

Daun binahong (Anredera cordifolia (Tenore) Steen) sebagai penyembuh luka melalui mekanisme antibakteri mengandung saponin, alkaloid, tanin, steroid, triterpenoid, flavonoid dan asam askorbat (Astuti et al., 2011). Keterangan tersebut memunculkan ide bagi peneliti untuk membuat ekstrak etanol daun binahong menjadi bentuk sediaan yang dapat digunakan untuk mengatasi infeksi luka diabetik yang terjadi pada kulit. Sediaan yang akan dibuat adalah sediaan dalam bentuk topikal berupa gel. Gel diketahui lebih efisien digunakan pada luka karena memberikan sensasi dingin pada luka, tidak meninggalkan bekas pada luka setelah dioleskan dan mudah meresap (Sari et al., 2013).

Penelitian Isabella (2010) tentang uji aktivitas ekstrak daun binahong sebagai antibakteri memaparkan bahwa Kadar Hambat Minimal (KHM) bakteri yang didapatkan adalah $10 \%$. Berdasarkan referensi tersebut, peneliti menggunakan variasi konsentrasi $10 \%$ sebagai konsentrasi terendah. Pada penelitian Isabella (2010) juga menyebutkan bahwa semakin besar konsentrasi ekstrak daun binahong yang digunakan, semakin sedikit bakteri yang tumbuh. Oleh sebab itu, untuk mengetahui efektivitas dari formula gel ekstrak etanol daun binahong sebagai penyembuh luka diabetik, peneliti juga membuat variasi konsentrasi $30 \%$.

Penelitian ini bertujuan untuk mengetahui konsentrasi ekstrak etanol daun binahong yang tepat pada proses penyembuhan luka diabetik dengan mengetahui berkurangnya sel radang polimorfonuklear netrofil akan berpengaruh pada tahap penyembuhan luka, khususnya pada fase inflamasi, sedangkan reepitelisasi akan mempercepat proses penyembuhan luka.

\section{METODE PENELITIAN}

Penelitian ini menggunakan metode eksperimental laboratorium untuk mengetahui keefektifan gel ekstrak etanol daun binahong 10\% dan 30\% terhadap penyembuhan luka diabetik pada tikus. Populasi dalam penelitian ini adalah tikus jantan galur Wistar dengan 
berat badan 160-250 gram, berumur 3-4 bulan. Sampel penelitian sebanyak 25 tikus dipilih secara acak yang dibagi dalam 5 kelompok dengan pengulangan sebanyak 5 kali.

\section{Pembuatan gel ekstrak etanol daun binahong}

Bahan yang digunakan adalah simplisia kering daun binahong. Simplisia daun binahong sebanyak 400 gram diblender dan diekstraksi dengan $1500 \mathrm{ml}$ etanol 96\%, kemudian digoyang 1 jam dalam shaker waterbath dengan kecepatan $120 \mathrm{rpm}$, dimaserasi selama 24 jam pada suhu kamar dan difiltrasi dengan corong Buchner setelah 24 jam. Residu penyaringan diremaserasi 24 jam, diulang sampai 3 kali. Hasil saringan 1 sampai 3 dicampur dan dipekatkan dengan Rotary vaccum evaporator dengan suhu $50^{\circ} \mathrm{C}$ sampai didapatkan ekstrak pekat (Umar et al., 2012).

Pada penelitian ini dibuat sediaan gel dengan variasi konsentrasi ekstrak yaitu $10 \%$ dan $30 \%$ sebanyak 25 gram untuk 28 kali pemakaian selama 14 hari pengamatan.

Formulasi gel ekstrak etanol daun binahong $10 \%$

$\mathrm{R} / \quad$ Ekstrak etanol daun binahong $2,5 \mathrm{~g}$

$\begin{array}{ll}\text { Na-CMC } & 1,25 \mathrm{~g} \\ \text { Gliserin } & 2,5 \mathrm{~g} \\ \text { Propilenglikol } & 1,25 \mathrm{~g} \\ \text { Aquadest } & \text { ad } 25 \mathrm{~g}\end{array}$

Formulasi gel ekstrak etanol daun binahong 30\%

$\mathrm{R} / \quad$ Ekstrak etanol daun binahong $7,5 \mathrm{~g}$

$\begin{array}{ll}\text { Na-CMC } & 1,25 \mathrm{~g} \\ \text { Gliserin } & 2,5 \mathrm{~g} \\ \text { Propilenglikol } & 1,25 \mathrm{~g} \\ \text { Aquadest } & \text { ad } 25 \mathrm{~g}\end{array}$

Ekstrak dilarutkan dalam sebagian air, dipanaskan pada suhu $50^{\circ} \mathrm{C}$, ditambahkan Na-CMC diaduk homogen, ditambahkan gliserin, propilen glikol, air diaduk hingga terbentuk gel. Gel yang telah terbentuk kemudian disimpan pada tempat yang gelap dan dingin selama semalam yaitu pada suhu $10^{\circ} \mathrm{C}-15^{\circ} \mathrm{C}$ (Hamzah, 2006).

\section{Evaluasi Sediaan Gel}

Uji organoleptik

Uji organoleptik dilakukan dengan melakukan pengamatan terhadap bentuk, warna dan bau dari sediaan gel yang telah dibuat (Anief, 1997).

Uji homogenitas

Uji homogenitas gel dilakukan pada plat kaca, diraba dan diterawang (Voight, 1995).

Pengamatan dilakukan pada hari ke-2, hari ke-4, dan hari ke-6.

Uji iritasi dan uji $\mathrm{pH}$

Gel 0,5 gram dioleskan pada punggung tiga ekor tikus yang telah dicukur rambutnya (kulit punggung tikus tidak boleh terluka). Pengamatan uji iritasi dilakukan pada 24 jam dan 72 jam setelah gel dioleskan pada punggung tikus. 
Uji daya sebar

Gel sebanyak 0,5 gram diletakkan di tengah kaca bulat berskala, di atasnya diletakkan kaca bulat transparan lain dan pemberat 150 gram, didiamkan 1 menit, dicatat diameter penyebarannya. Daya sebar gel yang baik antara 5 sampai $7 \mathrm{~cm}^{2}$ (Garg et al., 2002).

Uji konsistensi

Uji konsistensi dilakukan dengan cara mensentrifus gel pada kecepatan $3800 \mathrm{rpm}$ selama 5 jam. Diamati terjadinya pemisahan antara bahan pembentuk gel dan pembawanya (Djajadisastra et al., 2009).

\section{Pemberian Dosis Aloksan}

Pemberian aloksan monohidrat dengan dosis $150 \mathrm{mg} / \mathrm{kgBB}$ secara intraperitoneal, ditunggu 3 hari, kemudian diukur kadar glukosa darahnya (Triplitt et al., 2008). Tikus yang digunakan untuk pengujian adalah tikus dengan peningkatan kadar gula darah lebih dari $300 \mathrm{mg} / \mathrm{dL}$ (Romero et al., 2014).

\section{Prosedur Pembuatan Luka pada Hewan Uji}

Perlukaan pada K (-), K (+), KB 10\% dan KB 30\% dilakukan tiga hari setelah induksi aloksan, $\mathrm{KN}$ tidak diinduksi aloksan namun perlukaan tetap dibuat pada hari ke-3. Tikus diukur kadar glukosanya terlebih dahulu sebelum dilakukan perlukaan, diberikan Ketamin $\mathrm{HCl}$ dengan dosis $0,6 \mathrm{ml} / \mathrm{kg}$ BB secara intravena, dibuat pola dengan bentuk lingkaran berdiameter $1,5 \mathrm{~cm}$. Kulit bagian atas dipotong sesuai dengan pola yang dibuat, jangan sampai mengenai bagian otot. Luka didiamkan sampai terbentuk infeksi.

\section{Perlakuan pada Tikus}

Pada penelitian ini digunakan 25 ekor tikus, dibagi menjadi 5 kelompok. Perlakuan pada tikus yang akan dilakukan, antara lain:

Perlakuan A: tikus tidak diinduksi aloksan, luka hanya dibersihkan dengan $\mathrm{NaCl}$ 0,9\% [Kontrol Normal (KN)].

Perlakuan B: tikus diinduksi aloksan secara intraperitoneal dengan dosis $150 \mathrm{mg} / \mathrm{kgBB}$, luka dibersihkan dengan $\mathrm{NaCl} 0,9 \%$ [Kontrol Negatif $\{\mathrm{K}(-)\}]$.

Perlakuan C: tikus diinduksi aloksan secara intraperitoneal dengan dosis $150 \mathrm{mg} / \mathrm{kgBB}$, luka dibersihkan dengan $\mathrm{NaCl}$ 0,9\% dan diolesi Kloramfenikol krim ${ }^{\mathrm{TM}}, 2$ kali sehari [Kontrol Positif $\{K(+)\}]$.

Perlakuan D: tikus diinduksi aloksan secara intraperitoneal dengan dosis $150 \mathrm{mg} / \mathrm{kgBB}$, luka diolesi gel ekstrak daun binahong $10 \%$ dan dibersihkan dengan $\mathrm{NaCl}$ 0,9\%, 2 kali sehari [Kelompok Perlakuan Binahong Konsentrasi 10\% (KB $10 \%)]$.

Perlakuan E: tikus diinduksi aloksan secara intraperitoneal dengan dosis $150 \mathrm{mg} / \mathrm{kgBB}$, luka dioleskan gel ekstrak daun binahong 30\% dan dibersihkan dengan $\mathrm{NaCl}$ 0,9\%, 2 kali sehari [Kelompok Perlakuan Binahong Konsentrasi 30\% (KB 30\%)].

\section{Proses Pengambilan Jaringan}

Tikus dikorbankan dengan dislokasi serviks hari ke-16 dan hari ke-23 pasca perlukaan, kemudian diberi tanda pada bagian kulit yang akan diambil jaringannya. Jaringan yang diambil, yaitu jaringan yang diberikan perlukaan (jaringan luka) dan sebagian jaringan normal yang ada di sekitarnya, diletakkan hasil guntingan di atas karton (supaya kulit tidak menggulung), dimasukkan dalam cairan formalin, dilakukan pengamatan histopatologi jaringan kulit tikus dengan pewarnaan Haematoxyline dan Eosin (HE). 


\section{Pembacaan Preparat Histopatologi}

Pembacaan dilakukan terhadap sel radang polimorfonuklear (PMN) netrofil dan reepitelisasi pada jaringan kulit yang telah dibuat preparat. Pengamatan dilakukan menggunakan mikroskop cahaya dengan perbesaran 400 kali secara skoring (Freida, 1994), kemudian diinterpretasikan secara deskriptif kualitatif.

\section{PEMBAHASAN}

\section{Hasil uji evaluasi gel}

Hasil uji organoleptis semua sediaan gel berbentuk semipadat aroma khas ekstrak daun binahong. Rasa dari gel daun binahong cukup pahit, karena daun binahong memiliki kandungan alkaloid yang memiliki ciri khas rasa pahit (Anonim, 2008). Warna yang dihasilkan gel ekstrak etanol daun binahong dari semua variasi konsentrasi hijau tua, disebabkan kandungan klorofil yang tinggi di dalam daun binahong. Hasil pengujian homogenitas semua sediaan gel ekstrak etanol daun binahong homogen dan tidak menggumpal. Hasil uji iritasi pada kedua sediaan gel ekstrak etanol daun binahong tidak ditemukannya iritasi. Hasil uji $\mathrm{pH}$ yaitu 6,5 menunjukkan semua gel yang dihasilkan memenuhi kriteria $\mathrm{pH}$ kulit. Hasil uji daya sebar menunjukkan semua gel ekstrak etanol daun binahong dengan basis Na-CMC sudah memenuhi parameter daya sebar yang baik. Gel ekstrak etanol daun binahong konsentrasi $10 \%$ menunjukkan daya sebar sebesar 5,50 \pm $0,14 \mathrm{~cm}^{2}$ dan gel ekstrak etanol daun binahong konsentrasi $30 \%$ menunjukkan daya sebar sebesar 5,53 $\pm 0,10 \mathrm{~cm}^{2}$. Hasil uji konsistensi semua gel tetap stabil dan tidak terpengaruh gaya gravitasi untuk penyimpanan selama setahun karena tidak mengalami pemisahan (Djajadisastra et al., 2009).

\section{Hasil pengukuran kadar glukosa darah}

Pengambilan darah hari ke-0 untuk mengetahui kadar glukosa darah sebelum dilakukan perlukaan eksisi. Pemberian aloksan menimbulkan kondisi diabetes yang permanen dalam dua sampai tiga hari (Szkudelski 2001). Pengambilan data kadar glukosa darah dilakukan sebelum tikus dikorbankan hari ke-23 untuk membuktikan bahwa tikus masih dalam kondisi diabetes sampai akhir perlakuan. Hasil pengukuran pada Gambar 1 .

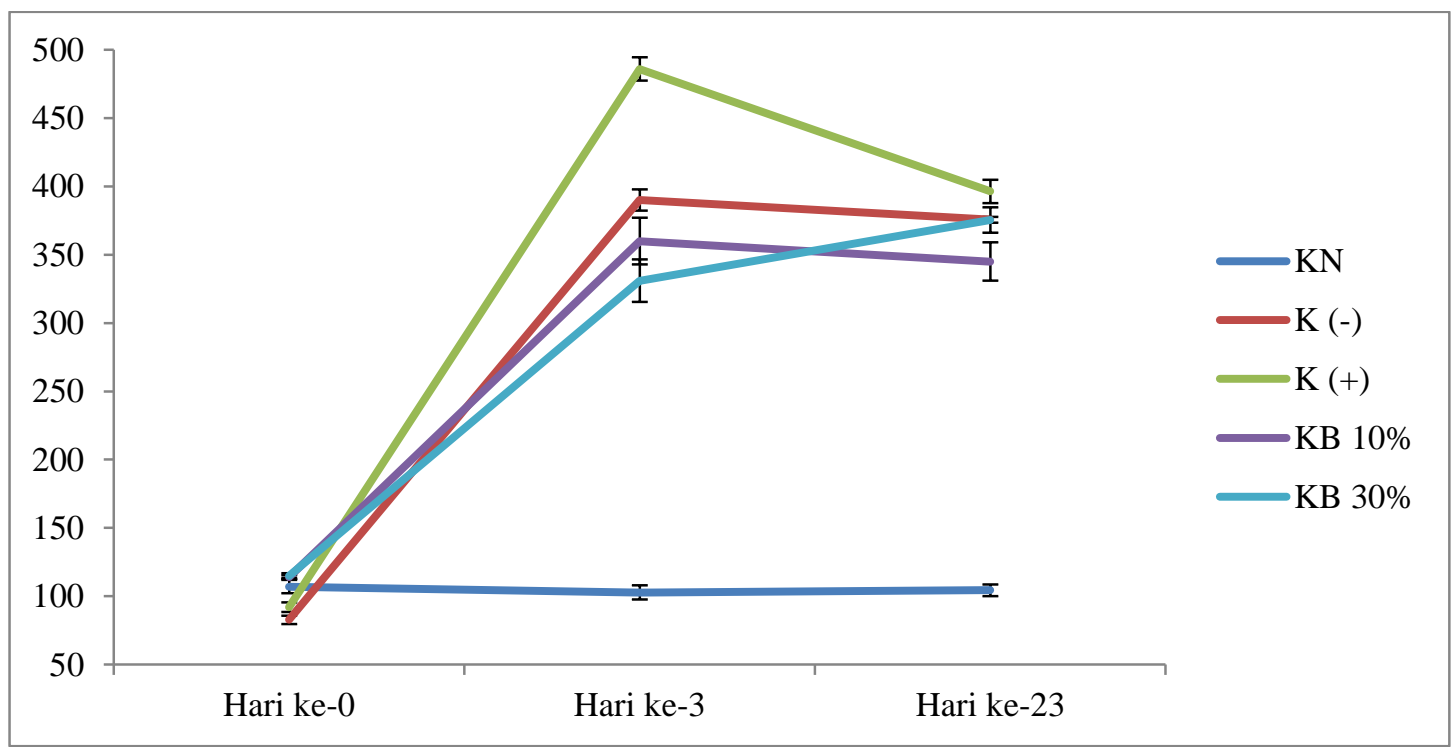

Gambar 3. Kadar glukosa darah lengkap (hari ke-0, hari ke-3 dan hari ke-23) 
Perubahan kadar glukosa darah terjadi pada $\mathrm{K}(-), \mathrm{K}(+), \mathrm{KB} 10 \%$, KB $30 \%$ hari ke-0 dibandingkan kadar glukosa darah hari ke-3 dan hari ke-23, KN relatif stabil. Hasil tersebut membuktikan tikus yang digunakan sesuai dengan kondisi yang dikehendaki peneliti, yaitu pada K (-), K (+), KB 10\% dan KB 30\% mengalami diabetes sampai akhir perlakuan, sedangkan pada KN tidak mengalami diabetes.

\section{Parameter Kondisi DM}

Hasil pengamatan gejala yang menyertai DM meliputi:

\section{Asupan Minum}

Data pengukuran asupan minum ini dilakukan sebelum perlakuan, yaitu pada hari ke-0 sampai perlakuan berlangsung, yaitu pada hari pertama hingga hari ke-23. Data pengukuran asupan minum dapat dilihat pada Gambar 2.

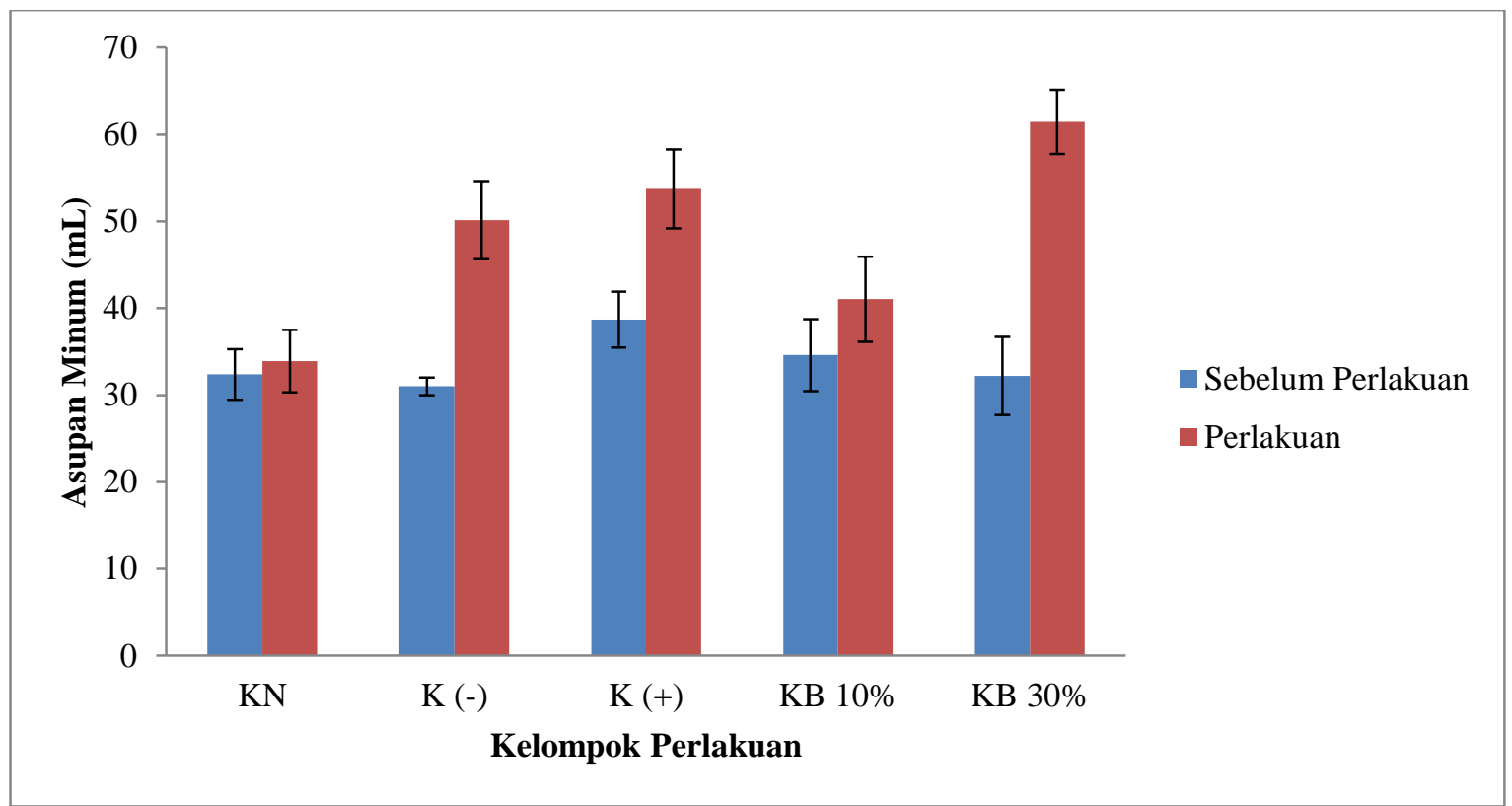

Gambar 4. Asupan minum rata-rata sebelum perlakuan dan perlakuan

Peningkatan asupan minum yang cukup tinggi terjadi pada K (-), K (+), KB 10\% dan $\mathrm{KB} 30 \%$, sedangkan pada $\mathrm{KN}$ tidak mengalami peningkatan asupan minum yang tinggi. Hal ini menunjukkan bahwa $\mathrm{K}(-), \mathrm{K}(+), \mathrm{KB} 10 \%$ dan $\mathrm{KB} 30 \%$ mengalami kondisi diabetes sampai akhir perlakuan sesuai dengan manifestasi yang muncul penderita DM yaitu selalu merasa haus atau polidipsia (Manaf, 2006).

Berat Badan

Hasil perubahan berat badan tikus selama penelitian dapat dilihat pada Gambar 3. 


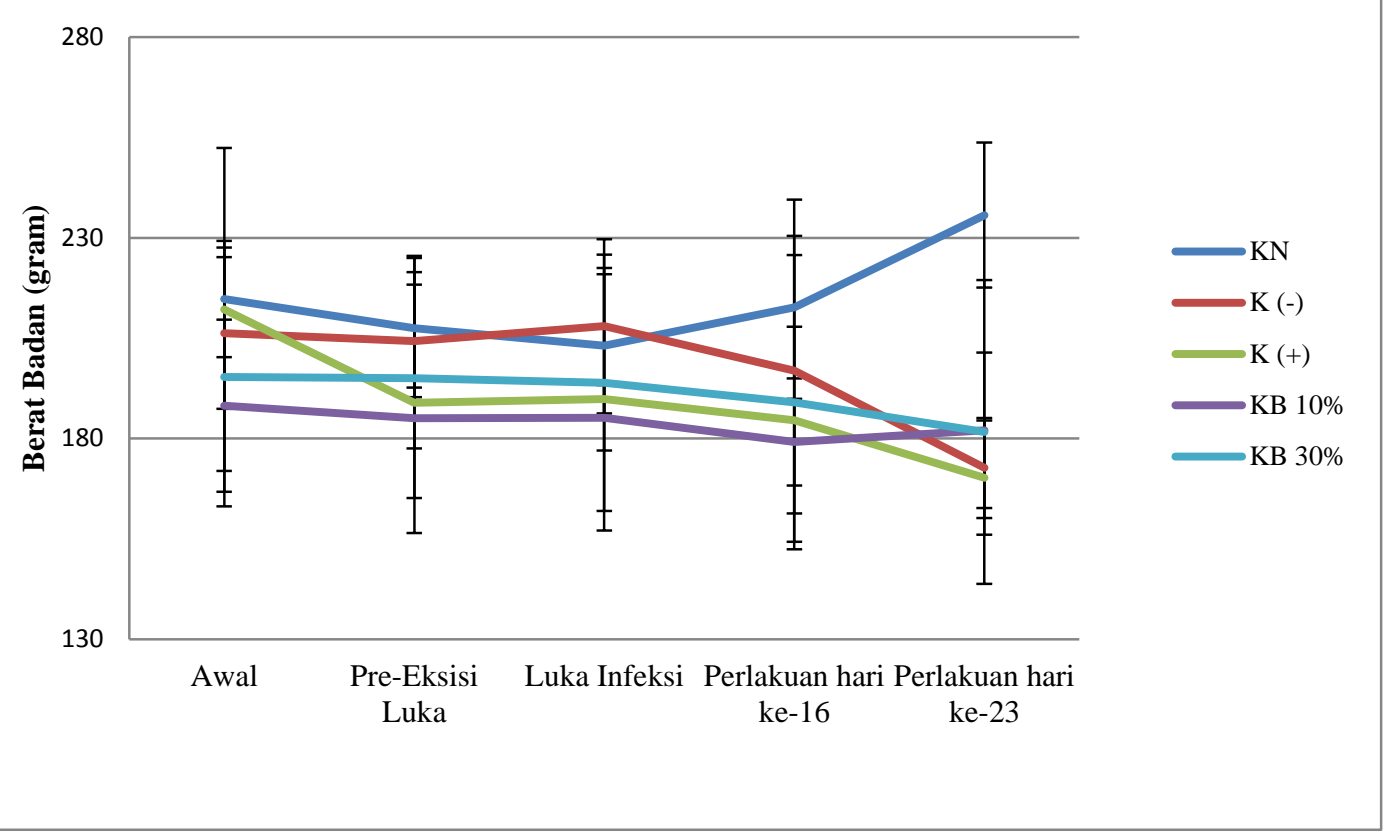

Gambar 5. Perubahan berat badan tikus selama penelitian

Penurunan berat badan pada K (-), K (+), KB 10\% dan KB 30\%, sedangkan pada KN mengalami kenaikan berat badan. Hal ini menunjukkan bahwa K (-), K (+), KB $10 \%$ dan $\mathrm{KB} 30 \%$ mengalami DM sampai akhir perlakuan sesuai dengan teori kondisi diabetes, yaitu mengalami penurunan berat badan (Manaf, 2006).

Asupan Pakan

Hasil pengukuran asupan pakan tikus selama penelitian pada Gambar 4.

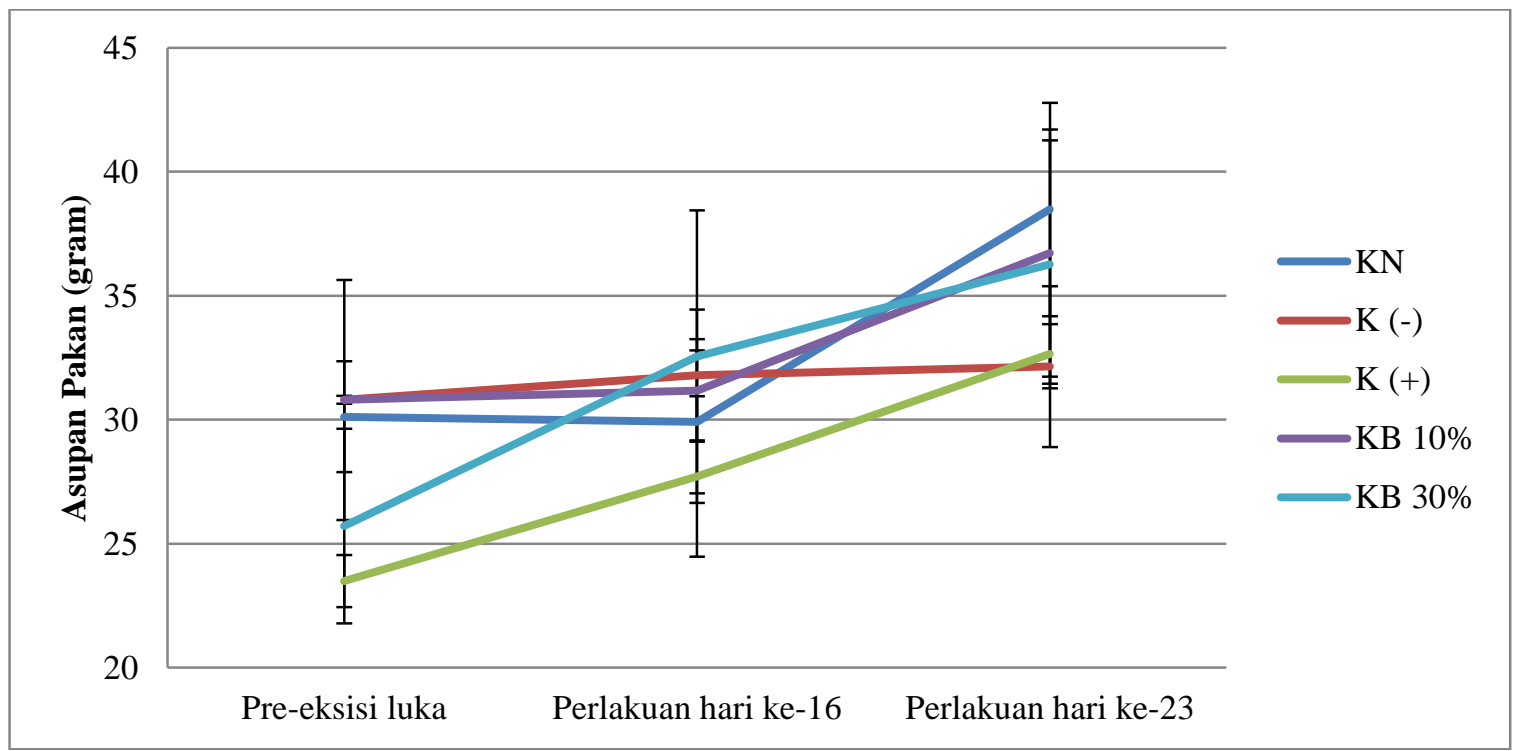

Gambar 6. Asupan pakan rata-rata selama penelitian 
Pada K (-), K (+), KB 10\%, K 30\% mengalami peningkatan asupan pakan pada preeksisi luka, perlakuan hari ke-16 dan perlakuan hari ke-23, sedangkan KN mengalami penurunan dan peningkatan asupan pakan. Pada umumnya penderita DM akan selalu merasa lapar atau nafsu makan meningkat polifagia (Manaf, 2006).

Rasio Efisiensi Pakan (FER)

Rasio efisiensi pakan merupakan hubungan berat badan dan asupan pakan tikus. Peningkatan FER ditunjukkan pada KN, sedangkan pada K (-), K (+), KB $10 \%$ dan KB $30 \%$ FER mengalami penurunan. FER yang besar, menunjukkan suatu kondisi di mana berat badan meningkat, asupan pakan juga meningkat. Hal ini berbeda pada kondisi diabetes, yang menunjukkan berat badan menurun, tetapi asupan pakan meningkat (Lee et al., 2004). Pada K (-), K (+), KB 10\% dan KB 30\% menunjukkan FER yang rendah. Hal ini membuktikan bahwa tikus $\mathrm{K}(-), \mathrm{K}(+), \mathrm{KB} 10 \%$ dan $\mathrm{KB} 30 \%$ mengalami diabetes hingga akhir perlakuan.

\section{Gambaran Histopatologi Organ Kulit}

Hasil skoring sel radang PMN netrofil dan skoring reepitelisasi pada Tabel 1, sedangkan gambaran hisopatologinya pada Gambar 5 dan Gambar 6.

Tabel 4. Hasil pembacaan skoring sel radang polimorfonuklear netrofil dan skoring reepitelisasi pada preparat histopatologi jaringan kulit

\begin{tabular}{lcc}
\hline \multicolumn{1}{c}{ Kelompok } & Sel radang PMN netrofil & Reepitelisasi \\
\hline KN hari ke-16 & +++ & ++++ \\
KN hari ke-23 & ++ & ++++ \\
K (-) hari ke-16 & ++++ & ++ \\
K (-) hari ke-23 & ++++ & ++ \\
K (+) hari ke-16 & +++ & +++ \\
K (+) hari ke-23 & + & ++++ \\
KB 10\% hari ke-16 & ++++ & ++ \\
KB 10\% hari ke-23 & ++++ & ++++ \\
KB 30\% hari ke-16 & + & ++ \\
KB 30\% hari ke-23 & ++ & ++++ \\
\hline
\end{tabular}

$\begin{array}{ll}\text { Keterangan: } & \\ + & =1 \\ ++ & =2 \\ +++ & =3 \\ ++++ & =4\end{array}$

Semakin banyak tanda $(+)$ berarti semakin tinggi skor

Hasil pengamatan skoring sel radang PMN netrofil pada KN menunjukkan sel radang PMN netrofil yang lebih sedikit dibandingkan dengan $\mathrm{K}(-)$. Pengamatan skoring reepitelisasi menunjukkan $\mathrm{KN}$ lebih cepat terlihat dibandingkan dengan $\mathrm{K}(-)$. Hal ini disebabkan pada KN merupakan luka normal (bukan luka diabetik) sehingga proses berakhirnya perbaikan jaringan dan dilanjutkan proses maturasi lebih cepat dibandingkan dengan $\mathrm{K}(-)$ yang merupakan luka diabetik. 


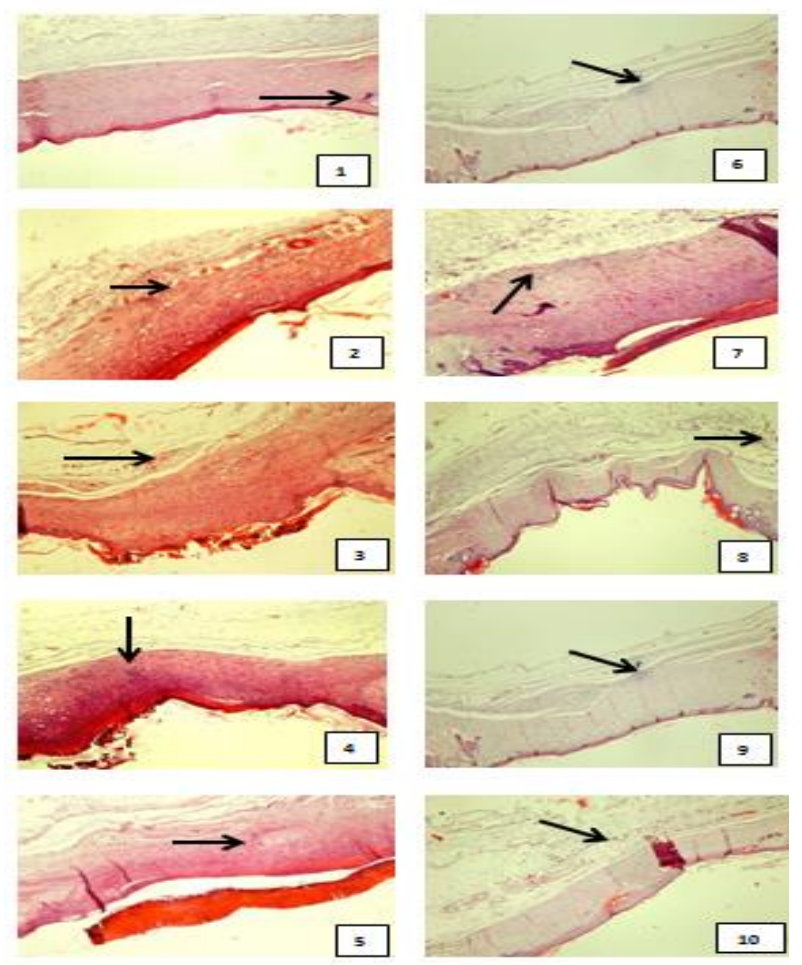

Gambar 7. Gambaran sel radang polimorfonuklear netrofil preparat histopatologi jaringan kulit

(1) KN hari ke-16, (2) $\mathrm{K}(-)$ hari ke-16, (3) $\mathrm{K}(+)$ hari ke-16, (4) KB $10 \%$ hari ke-16, (5) KB $30 \%$ hari ke-16, (6) KN hari ke-23, (7) K(-) hari ke-23, (8) $\mathrm{K}(+)$ hari ke-23, (9) KB 10\% hari ke-23, (10) KB 30\% hari ke-23.

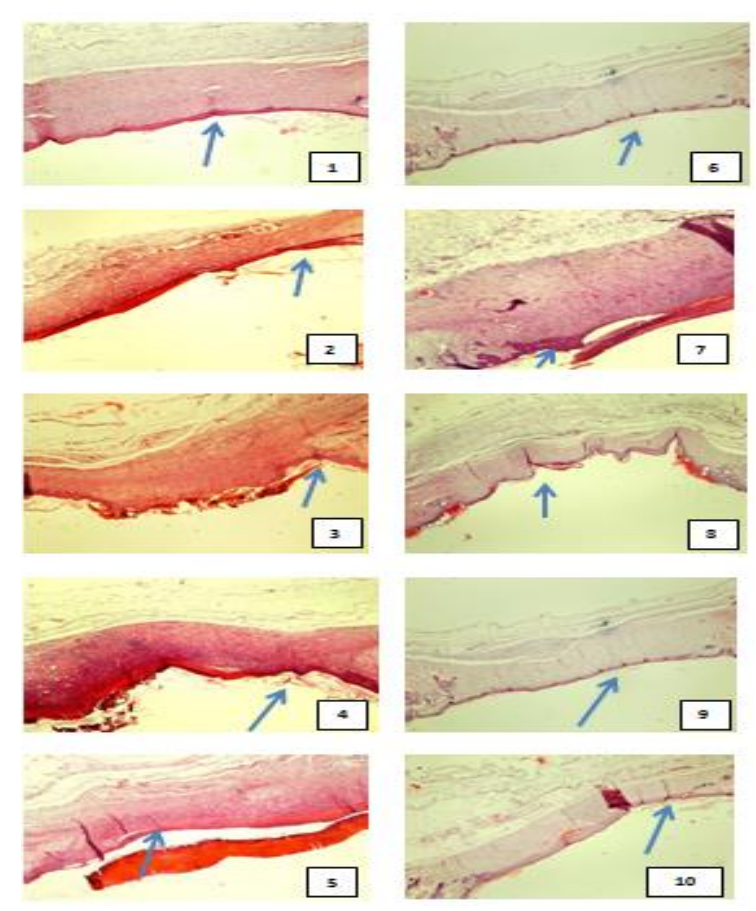

Gambar 8. Gambaran reepitelisasi preparat histopatologi jaringan kulit

(1) KN hari ke-16, (2) $\mathrm{K}(-)$ hari ke-16, (3) $\mathrm{K}(+)$ hari ke-16, (4) KB $10 \%$ hari ke-16, (5) KB $30 \%$ hari ke-16, (6) KN hari ke-23, (7) K (-) hari ke-23, (8) K (+) hari ke-23, (9) KB 10\% hari ke-23, (10) KB 30\% hari ke-23. 
Hasil pengamatan skoring sel radang PMN netrofil pada $\mathrm{K}(+)$ menunjukkan penurunan sel radang PMN netrofil yang jauh lebih banyak dibandingkan dengan K (-). Pengamatan skoring reepitelisasi pada $\mathrm{K}(+)$ lebih banyak terbentuk dibandingkan dengan K (-). Menurut Suriadi dalam Purbianto (2007), penyebab dari luka diabetik salah satunya adalah infeksi. Infeksi terdiri dari bermacam-macam bakteri. Bakteri yang lazim menginfeksi luka diabetik umumnya Staphylococcus aureus (gram positif) dan Streptococcus pyogenes (gram positif). Kloramfenikol krim ${ }^{\mathrm{TM}}$ digunakan sebagai K (+), sebab bersifat bakteriostatik dengan mekanisme kerja melalui penghambatan terhadap biosintesis protein pada siklus pemanjangan rantai asam amino, yaitu dengan menghambat pembentukan ikatan peptida (Ganiswarna, 1995). Kloramfenikol krim TM ini mampu mengikat subunit ribosom 50-S sel mikroba target secara terpulihkan, akibatnya terjadi hambatan pembentukan ikatan peptida dan biosintesis protein. Terhambatnya pembentukan ikatan peptida menyebabkan transport protein akan terganggu, (Cowan, 1999). Sel bakteri tidak dapat terbentuk karena materi genetik sel bakteri tersusun atas protein. Tidak terbentuknya sel bakteri akan menyebabkan infeksi dan inflamasi berkurang sehingga menghambat pertumbuhan sel radang PMN netrofil. Infeksi luka merupakan salah satu komplikasi luka. Infeksi dapat menghambat terjadinya reepitelisasi (InETNA, 2004). Pada penjelasan sebelumnya, mekanisme antibakteri dalam Kloramfenikol krim ${ }^{\mathrm{TM}}$ dapat mengurangi infeksi dan inflamasi pada kasus luka DM, sehingga untuk mempercepat reepitelisasi, maka infeksi harus dikurangi. Hal ini terbukti pada gambaran mikroskopis beberapa $\mathrm{K}(+)$, yang menunjukkan skoring reepitelisasi yang besar pada hari ke-23. Penelitian Barequet et al., (2014) menunjukkan bahwa Kloramfenikol krim ${ }^{\mathrm{TM}}$ dapat digunakan secara efektif dalam mempercepat proses reepitelisasi pada erosi kornea. Erosi kornea merupakan suatu keadaan terlepasnya epitel kornea yang disebabkan karena adanya trauma tumpul ataupun tajam pada kornea. Hal ini dapat disamakan dengan kondisi luka eksisi yang dibuat dalam penelitian ini. Luka eksisi dibuat dengan cara mengambil jaringan berikut dengan pembungkusnya (kulit), sehingga pada luka eksisi juga mengalami kondisi kehilangan jaringan epitel (Soegeng, 2004). Hal tersebut memperkuat bukti bahwa Kloramfenikol krim ${ }^{\mathrm{TM}}$ mampu mempercepat proses reepitelisasi pada penyembuhan luka.

Pada KB $10 \%$ sel radang PMN netrofil masih banyak terlihat pada hasil skoring hingga hari ke-23 dibandingkan dengan K (-). Pada hasil skoring reepitelisasi KB 10\% menunjukkan pembentukan epitel yang banyak pada hari ke-23 jika dibandingkan dengan $\mathrm{K}(-)$. Hal ini menunjukkan bahwa pemberian gel ekstrak etanol daun binahong konsentrasi $10 \%$ mempunyai kemampuan mempercepat penutupan luka dengan proses reepitelisasi. Mekanisme antibakteri yang terkandung dalam daun binahong dapat merangsang pembentukan sel epitel yang baru dan mendukung proses epitelisasi sehingga dapat mempersingkat proses penyembuhan luka (Napanggala et al., 2012). Suatu luka dapat dikatakan sembuh apabila daerah luka tersebut telah mengalami epitelisasi secara menyeluruh dan tidak lagi membutuhkan perawatan (Schmidt dalam Handayani, 2006).

Penurunan sel radang PMN netrofil yang menyebar terlihat pada hasil skoring KB $30 \%$ hingga hari ke-23, sebab daun binahong mampu menghambat siklooksigenase dan lipooksigenase sehingga terjadi pembatasan jumlah sel radang PMN netrofil yang bermigrasi ke jaringan perlukaan, sehingga reaksi inflamasi akan berlangsung lebih singkat dan kemampuan proliferatif dari TGF- $\beta$ tidak terhambat, sehingga mengakibatkan fase proliferasi dapat segera terjadi (Napanggala et al., 2012). Hal ini menunjukkan bahwa gel ekstrak etanol daun binahong konsentrasi 30\% memberikan efek yang baik terhadap penurunan jumlah sel radang PMN netrofil. Pada skoring KB 30\% hari ke-23 menunjukkan bahwa pada kelompok ini sudah terbentuk reepitelisasi yang cukup tebal dan sempurna, sedangkan pada K (-) belum terbentuk sempurna. Hal tersebut membuktikan 
daun binahong berperan dalam penyembuhan luka, melalui mekanisme antibakteri dalam peningkatan kecepatan epitelisasi yang memulai proses penyembuhan luka (Triyono, 2005).

\section{KESIMPULAN DAN SARAN}

\section{Kesimpulan}

1. Ekstrak etanol daun binahong dengan konsentrasi 30\% dapat memberikan efektivitas terbaik dalam menyembuhkan luka diabetik dibuktikan dengan berkurangnya sel radang polimorfonuklear $(\mathrm{PMN})$ netrofil dan terbentuknya reepitelisasi.

2. Pengaruh penggunaan basis gel Na-CMC terhadap evalusi sediaan gel ekstrak etanol daun binahong juga menunjukkan hasil yang sesuai dengan teori sediaan gel yang baik.

\section{Saran}

Perlu dilakukan penelitian lebih lanjut tentang formulasi yang baik dengan deklorofilisasi untuk menghilangkan warna hijau pekat pada gel.

\section{UCAPAN TERIMA KASIH}

Ucapan terima kasih kepada Kopertis Wilayah V yang telah mendukung penelitian dalam bentuk pembiayaan dari DIPA tahun 2015.

\section{DAFTAR PUSTAKA}

Anief, M. Ilmu Meracik Obat. Yogyakarta: Gadjah Mada University Press, 1997.

Astuti, S.M., Mimi, S.A.M., Awalludin, R.. Active Substances of Anredera cordifolia (Tenore) Steenis in the Phytochemical Constituent, $1^{\text {st }}$ International Conference and Exhibition of Women Engineers (ICEWE, 2011). Malaysia: Bukit Gambang Resort, Kuantan, Pahang. 2011.

Anonim, Farmakope Herbal Indonesia, Edisi I, Jakarta: Departemen Kesehatan Republik Indonesia, 2008.

Barequet, I.S., Harizman, N.Z., Rosner, H.M., Healing rate of corneal erosions: comparison of the effect of chloramphenicol eye drops and ointment and highconcentration hyaluronic acid in an animal model, US: US National Library of Medicine National Institute of Health Journal. 2014; 33(10):1080.

Cowan, M.M. Plant Product as Antimicrobial Agents. Journal Microbiology Reviews. 1999; 12(4) : 564-582.

Djajadisastra, J., A. Mun'im, Dessy. N.P. Formulasi Gel Topikal dari Ekstrak Nerii Folium dalam Sediaan Anti Jerawat. Jakarta: Jurnal Farmasi Indonesia. 2009: 4(4): 210-216.

Freida L.C. Histotechnology a Self Instructional Test, Chicago; American Clinical Pathologist ASCP Press. 1994.

Ganiswarna, V.H.S. Farmakologi dan Terapi Edisi ke-4. Jakarta: Bagian Farmakologi Fakultas Kedokteran Universitas Indonesia. 1995; 571,657-660.

Garg, A., Aggarwal, D., Garg, S., Sigla, A. K. Spreading of Semisolid Formulation: An Update, India: Pharmaceutical Technology. 2002; 84-102.

Hamzah, M.M. Anti Inflammatory Activity of Achillea and Ruscus Topical Gel on Carrageenan-Induced Paw Edema in Rats, Acta Poloniae Pharmaceutica Drug Research Journal, 2006; 63(4): 277-280.

Handayani I. Aktivitas sediaan gel dari ekstrak lidah buaya (Aloe barbadensis Miller) untuk proses persembuhan luka pada mencit (Mus musculus) (Skripsi). Bogor: Fakultas Kedokteran Hewan Institut Pertanian Bogor. 2006. 
Isabella R., Sumarno, Pudjo S. Uji efektivitas ekstrak daun binahong (Anredera cordifolia (Ten.) Stennis) sebagai anti mikroba terhadap pseudomonas aeruginosa secara in vitro (Naskah Publikasi), 2010.

InETNA (Indonesia Enterostomal Therapy Nurse Association), Perawatan Luka. Jakarta: RS Dharmais. 2004; 5-15.

Junaidi, I. Kencing Manis. Jakarta: Kelompok Gramedia. 2009.

Manaf, A. ed. Aru, W. Insulin :Mekanisme Sekresi dan Aspek Metabolisme. Ilmu Penyakit Dalam Jilid III Edisi keempat. Jakarta:Fakultas Kedokteran Universitas Indonesia. 2006.

Margolis, D.J., Gupta, J., Hoffstad, O., Papdopoulos, M., Glick, H.A., Thom, S.R., Mitra, N. Lack of Effectiveness of Hyperbaric Oxygen Therapy for the Treatment of Diabetic Foot Ulcer and the Prevention of Amputation: A Cohort Study. US: US National Library of Medicine National Institute of Health Journal . 2013; 36(7):1961-1966.

Napanggala, A. Susianti. Apriliana, E. Pengaruh Pemberian Getah Tanaman Jarak Pagar (Jatropa curcas L.) secara Topikal terhadap Tingkat Kesembuhan Luka Iris pada Tikus Putih Jantan Galur Sprague dawley, Lampung: Journal Kedokteran Fakultas Kedokteran Universitas Lampung. 2012.

Purbianto. Pengaruh madu dalam mempercepat proses penyembuhan ulkus diabetikum di RSUD dr. H. Abdul moeloek Lampung. (Tesis). Lampung: Universitas Lampung. 2007.

Romero, C. Zamilpa, A. Díaz, G. Tortoriello, J. Pharmacological Effect of Ageratina pichinchensis on Wound Healing in Diabetic Rats and Genotoxicity Evaluation. Journal Ethnopharmacology. 2014; 156: 222-227.

Sari, Y. Dhadhang. Saryono. Arrington, I.G. Nakatani, T. Nigella sativa Gel Improves Granulation and Reepithelization Tissue of Diabetic Rats, Purwokerto: International Conference on Sustainable Rural Development (ICSRD), Indonesia. 2013.

Smyth S.H.A. Diabetes and obesity: the twin epidemics. Nature Medicine Journal. 2006; 12:75-80.

Soegeng, B. Petunjuk Skill Lab Insisi dan Drenase, Semarang: Fakultas Kedokteran Universitas Islam Sultan Agung. 2004.

Szkudelski, T. The Mechanism of Alloxan and Streptozotocin Action in beta Cells of the Rat Pancreas, Physiology Research Journal. 2001; (50): 536-546.

Triplitt, C.L. Reasner, C.A. Isley, W.L. Diabetes Mellitus, Pharmacotherapy:A Pathophysiologic Approach $7^{\text {th }}$ edition. United States of America:The McGraw-Hill Companies Inc., 2008; 1205,1207, 1209, 1213.

Triyono B. Perbedaan Tampilan Kolagen di Sekitar Luka Insisi pada Tikus Wistar Yang Diberi Infiltrasi Penghilang Nyeri Levobupivakain dan yang Tidak Diberi Levobupivakain (Tesis). , Semarang: Universitas Diponegoro. 2005.

Umar, A. Krihariyani D. Mutiarawati, D.T. Pengaruh Pemberian Ekstrak Daun Binahong (Anredera cordifolia (Ten.) steenis) terhadap Kesembuhan Infeksi Staphylococcus aureus pada Mencit. Analis Kesehatan Sains. 2012; 1(2): 68-75.

Voight, R. ed Soewandhi, S.N. Buku Pelajaran Teknologi Farmasi. Yogyakarta: Universitas Gadjah Mada Press. 1995; 564-568.

WHO ed dr. Arisman, Hipokrates Pencegahan Diabetes Mellitus Jakarta: Laporan Kelompok Studi WHO. 2000. 